\title{
DAMPAK EFIKASI DIRI DALAM MENCEGAH PERILAKU SEKS BEBAS PADA
} REMAJA

\author{
(The Impact of Self-Efficacy in Avoiding Free Sex Behaviors among Adolescent) \\ Purwaningsih Purwaningsih, Retno Indarwati and Heni Murti Wahyuni \\ Fakultas Keperawatan, Universitas Airlangga, Surabaya, Indonesia
}

RIWAYAT ARTIKEL

Diterima: 5 Desember 2018 Disetujui: 9 Februari 2019

\section{KONTAK PENULIS}

Heni Murti Wahyuni heni.murti.wahyuni2017@fkp.unair.ac.id Fakultas Keperawatan, Universitas Airlangga

\begin{abstract}
ABSTRAK
Pendahuluan: Self-efficacy dalam menghindari seks bebas dan HIV/AIDS akan berdampak pada perilaku seksual remaja. Semakin baik self-efficacy remaja maka perilaku seksual semakin tidak berisiko. Tujuan dari penelitian ini adalah untuk mengetahui hubungan self-efiicacy dalam menghindari seks bebas dan HIV/AIDS dengan perilaku seksual remaja.
\end{abstract}

Metode: Penelitian berdesain korelasional dengan pendekatan cross-sectional. Populasi pada penelitian ini adalah remaja usia 17-19 tahun di SMK Kota Blitar dengan jumlah sampel sebanyak 127, diambil dengan teknik simple random sampling. Variabel independen dalam penelitian ini adalah self-efficacy dalam menghindari seks bebas dan HIV/AIDS. Variabel dependen dalam penelitian ini perilaku seksual remaja. Alat ukur yang digunakan berupa kuesioner. Analisa data menggunakan analisa univariat dan bivariat dengan uji Spearman-rho.

Hasil: Hasil menunjukkan variabel self-efficacy (magnitude, generalizability, the strength of belief) kategori rendah, dan perilaku seksual remaja (pengetahuan, sikap, dan tindakan) kategori berisiko. Self-efficacy dalam menghindari seks bebas dan HIV/AIDS berhubungan dengan perilaku seksual remaja ( $p=0,000 ; r=-0.448)$.

Kesimpulan: Dapat disimpulkan bahwa ada hubungan signifikan yang cukup kuat dan tidak searah antara self-efficacy dalam menghindari seks bebas dan HIV/AIDS dengan perilaku seksual remaja. Peneliti selanjutnya diharapkan dapat meneliti faktor-faktor lain yang mempengarhui peningkatan self-efficacy dalam menghindari seks bebas dan HIV/AIDS, sehingga dapat menurunkan angka perilaku seksual berisiko pada remaja.

\section{Kata Kunci}

self-efficacy, perilaku, seksual, remaja

\section{ABSTRACT}

Introduction: Self-efficacy in avoiding free sex and HIV/AIDS will have an impact on adolescent sexual behavior. As well as the increasing of their self-efficacy, their sexual behavior will be more healthier. This study was aimed to determine the correlation between self-efficacy in avoiding free sex and HIV/AIDS with adolescent's sexual behavior.

Method: This was correlational study with cross-sectional approach. The populations were adolescents aged 17-19 years in Senior High School at Blitar City. Total samples were 127 respondents, taken by using simple random sampling technique. Independent variabel was self-efficacy in avoiding free-sex. Dependent variable was adolescent sexual behavior. Data were collected by using questionnaires. Data were then analyzed by using univariate and bivariate analysis with Spearman-rho test.

Result: The results showed a low category of self-efficacy (magnitude, generalizability, the strength of belief), and the adolescent sexual behavior (knowledge, attitudes, and actions) in the risk category. Self-efficacy in avoiding free sex and HIV/AIDS correlate significantly with adolescent sexual behavior ( $\mathrm{p}=0.000 ; \mathrm{r}=-0.448)$.

Conclusion: It can be concluded that there is a significant and quite unidirectional relationship between self-efficacy in avoiding free sex and HIV/AIDS with adolescent 
Kutip sebagai: sexual behavior. Future research iexpected to be able to examine other factors that influence the increase in self-efficacy in avoiding free sex and HIV/AIDS, to reduce the rate of risky sexual behavior in adolescents.

\section{Keywords}

self-efficacy, sexual behavior, adolescent

Purwaningsih, P., Indarwati, R., \& wahyuni, H. M. (2019). Dampak Efikasi Diri Dalam Mencegah Perilaku Seks Bebas Pada Remaja. Indonesian J. of Community Health Nurs. J., 4(1), 17-22. Doi: 10.20473/ijchn.v4i1.12354

\section{PENDAHULUAN}

Risiko kesehatan seksual dan reproduksi remaja terus menjadi tantangan bagi peningkatan kesejahteraan remaja secara keseluruhan. Saat ini angka perilaku seks bebas pada remaja mengalami peningkatan (Morrison-Beedy et al., 2017). Peningkatan angka perilaku seks bebas pada remaja dapat menimbulkan masalah kesehatan seperti rentan tertular atau menularkan penyakit menular seksual (PMS) serta HIV/AIDS (Puspita, 2017). Data Pengadilan Agama Blitar menyebutkan bahwa selama tahun 2018 mulai Januari hingga September tercatat 120 pengajuan dispensasi menikah untuk melangsungkan pernikahan dibawah umur. Seluruhnya disebabkan karena kondisi perempuan hamil terlebih dahulu. Hasil wawancara kepada 5 remaja pada bulan Oktober 2018 dengan kasus hamil diluar pernikahan di Kota Blitar, mengatakan bahwa alasan melakukan seks sebelum menikah tidak menggunakan pengaman adalah karena ketidakpercayaan diri dalam menghindarkan diri dari tindakan yang dilakukan oleh teman sebayanya.

Salah satu faktor yang menyebabkan perilaku seks bebas pada remaja adalah tingkat kemampuan self-efficacy remaja dalam menjauhi perilaku beresiko yang masih rendah (Muflih dan Setiawan, 2017). Self-efficacy merupakan keyakinan seseorang tentang kemampuannya sendiri untuk menghadapi masalah di lingkungannya (Bandura, 1998). Remaja yang mendekati tuntutan dewasa diharuskan belajar memikul tanggung jawab terhadap diri sendiri dalam setiap dimensi kehidupan (Winarni, 2017). Efikasi diri menjadi satu determinan perubahan perilaku manusia karena diketahui sebagai penentu bagaimana orang merasa, berfikir, memotivasi diri, dan berperilaku (Bandura, 1998). Remaja dapat memperkuat rasa efficacy dengan belajar bagaimana bisa sukses dalam menghadapi berbagai masalah.

Pemerintah daerah Blitar sampai saat ini sedang menerapkan program Getting Zero Infection sebagai wujud penguatan komunitas. Program yang telah dijalankan antara lain sosialisasi terkait perilaku seks beresiko, NAPZA, kesehatan reproduksi serta pencegahan dan penularan HIV/AIDS melalui: 1) Kegiatan "GENRE" (Generasi Berencana) yang dinaungi oleh BKKBN, serta 2) Program komisi penanggulangan HIV/AIDS dari Dinas Kesehatan Kota Blitar. Teknik yang sering digunakan oleh lembaga terkait adalah metode ceramah. Akan tetapi berdasar keterangan BKKBN Kota Blitar, sampai saat ini metode belum terbukti efektif sehingga perlu untuk mengetahui hubungan self-efficacy dalam menghindari seks bebas dan penularan HIV/AIDS dengan perilaku seksual remaja.

Remaja rentan terhadap perilaku seksual berisiko karena impulsifitas dan perasaan kebal mereka (Muflih dan Setiawan, 2017). Sebanyak 60\% remaja mengaku telah melakukan seks pra nikah dan 50\% dari pengidap HIV dan AIDS adalah kelompok usia remaja. Dampak buruk dari perilaku seks bebas inilah yang menyebabkan remaja Indonesia terganggu kesempatannya untuk melanjutkan sekolah, memasuki dunia kerja, berkeluarga, dan menjadi masyarakat yang baik (Afritayeni, Yanti and Angrainy, 2018). Dampak lain adanya perilaku seksual pranikah pada remaja adalah dapat menimbulkan rasa bersalah, takut, cemas, apabila terjadi kehamilan dapat dikucilkan dari masyarakat, timbul perasaan malu dan depresi. Dampak fisiologis perilaku seksual pranikah adalah dapat mengakibatkan kehamilan tidak diinginkan sehingga melakukan tindakan aborsi, tertular penyakit seksual seperti HIV AIDS, sifilis (Istiqomah dan Notobroto, 2017).

Cara yang dapat dilakukan remaja untuk menghindari perilaku beresiko adalah memperkuat rasa efficacy. Self-efficacy dapat membantu seseorang untuk bisa sukses dalam menghadapi berbagai masalah (Winarni, 2017). Self-efficacy memiliki peran sebesar 86\% yang memengaruhi perilaku promosi kesehatan. Berdasarkan teori oleh Albert Bandura, self-efficacy merupakan tingkat kepercayaan diri yang terdiri dari subvariabel Magnitude, Generalizability, dan Strength of belief. Magnitude adalah penilaian kemampuan diri atas dasar penilaian tingkat kesulitan tugas atau tindakan yang diyakini seseorang untuk dilakukan, Generalizability merupakan hasil penilaian tingkat kemampuan diri yang dibatasi oleh fakta-fakta domain aktifitas. Sedangkan The Strength of belief ialah kekuatan keyakinan individu atas kemampuan dirinya mengatasi situasi dan kondisi di lingkungannya (Bandura, 1998). Tujuan dari penelitian ini adalah untuk mengetahui hubungan self-efiicacy dalam menghindari seks bebas dan HIV/AIDS dengan perilaku seksual remaja. 


\section{METODE}

Desain penelitian ini korelasional dengan pendekatan cross-sectional study. Populasi pada penelitian ini adalah remaja usia 17-19 tahun di SMKN 1 Kota Blitar dengan jumlah sampel sebanyak 127. Sampel diambil dengan teknik Simple Random Sampling. Variabel independen dalam penelitian ini adalah self-efficacy dalam menghindari seks bebas dan penularan HIV/AIDS. Variabel dependen dalam penelitian ini adalah perilaku seksual remaja. Data dikumpulkan dengan kuesioner. Data yang diperoleh kemudian di analisa menggunakan analisa univariat dan bivariat dengan uji Spearman-rho.

Penelitian ini telah lulus uji etik dari Komisi Etik Penelitian Kesehatan Fakultas Keperawatan Universitas Airlangga Surabaya dengan nomor 1235KEPK dan dilaksanakan di SMK Kota Blitar pada tanggal 14 Desember 2018. Proses pengambilan dan pengumpulan data selama penelitian menggunakan alat ukur berupa kuesioner Self-efficacy dalam menghindari seks bebas dan HIV/AIDS milik Muflih dan Setiawan (2017) yang telah dilakukan uji validitas dan reliabilitas. Uji reliabilitas $r$ Alpha Cronbach $\geq 0,7$ dengan $n=30$. Hasil uji reliabilitas $r \geq$ $0.7, n=30$. Dengan nilai Magnitude mendapatkan nilai $r>0.71$, Generalizability mendapatkan nilai $r>$ 0.75 , Strength of Belief mendapatkan nilai $r>0.88$. Kuesioner kedua mengenai perilaku seksual remaja milik Muflih dan Syafitri (2018) yang telah dilakukan uji validitas menggunakan uji statistic pearson product moment dengan $r$ tabel. Nilai $r$ tabel mengacu pada jumlah sampel 30 responden adalah $0.361(\alpha=0.05)$. Hasil uji reliabilitas didapatkan bahwa ketiga kuesioner bernilai diatas $0.7, \mathrm{n}=30$ ); Pengetahuan memiliki nilai $\mathrm{r}$ alpha cronbach 0.73 , Sikap memiliki nilai $\mathrm{r}$ alpha cronbach 0.70 , Tindakan memiliki nilai $\mathrm{r}$ alpha cronbach 0.89 . Artinya, kedua kuesioner valid dan reliabel untuk digunakan.

\section{HASIL}

Pada tabel 1 dapat dilihat bahwa rentang usia remaja dewasa akhir seluruhnya menjadi responden. Jumlah responden terbanyak adalah usia 17 tahun (45.7\%). Jenis kelamin responden sebagian adalah perempuan (52\%), jumlah tersebut tidak berbanding jauh dengan laki-laki yaitu (48\%). Sebagian responden saat ini memiliki status berpacaran, dan hampir seluruh responden $(83.5 \%)$ menyatakan pernah berpacaran sebelumnya hal ini menunjukkan bahwa responden telah memiliki pengalaman dalam berpacaran sebelumnya. Sehingga perilaku yang ditunjukkan merupakan hasil belajar dari pengalaman sebelumnya.

Dari 127 siswa/i yang menjadi responden, hampir seluruhnya mengatakan bahwa pernah menerima informasi mengenai cara menghindari perilaku seksual beresiko serta cara menghindari seks bebas dan HIV/AIDS. Berdasarkan analisis data responden, faktor yang dapat membantu menghindarkan diri dari perilaku beresiko, 76 siswa/i menyatakan bahwa dukungan sosial yang paling berpengaruh.
Sementara, sangat sedikit responden (15 siswa) yang menyatakan bahwa kepercayaan diri/self-efficacy merupakan faktor yang paling berpengaruh dalam menghindari perilaku seksual dan penularan HIV/AIDS. Artinya, remaja belum memahami bahwa faktor yang berpengaruh dalam menghindari perilaku seksual beresiko, selain faktor lingkungan dan dukungan orang sekitar utamanya adalah faktor dari dalam diri individu, khususnya kepercayaan diri sendiri dalam mengatasi/menghindari masalah (selfefficacy). Dari 127 siswa/i yang menjadi responden, hampir seluruhnya mengatakan bahwa pernah menerima informasi mengenai cara menghindari perilaku seksual beresiko serta cara menghindari seks bebas dan HIV/AIDS. Berdasarkan analisis data responden, faktor yang dapat membantu menghindarkan diri dari perilaku beresiko, 76 siswa/i menyatakan bahwa dukungan sosial yang paling berpengaruh. Sementara, sangat sedikit responden (15 siswa) yang menyatakan bahwa kepercayaan diri/self-efficacy merupakan faktor yang paling berpengaruh dalam menghindari perilaku seksual dan penularan HIV/AIDS. Artinya, remaja belum memahami bahwa faktor yang berpengaruh dalam menghindari perilaku seksual beresiko, selain faktor lingkungan dan dukungan orang sekitar utamanya adalah faktor dari dalam diri individu, khususnya kepercayaan diri sendiri dalam mengatasi/menghindari masalah (self-efficacy).

Pada tabel 2 dapat dilihat bahwa self-efficacy dalam menghindari seks bebas dan HIV/AIDS cenderung rendah. Hal ini dibuktikan dengan sebanyak 65 responden (51\%) termasuk dalam kategori rendah. Hal ini menunjukkan bahwa dari ketiga komponen self-efficacy dalam menghindari seks bebas dan HIV/AIDS, meskipun remaja memiliki kekuatan keyakinan dalam diri yang baik namun belum mampu menghadapi masalah bila dihadapkan dengan level/tingkatan masalah yang lebih tinggi dari keyakinannya, serta belum mampu mengontrol perilaku seksual dalam kehidupan sehari-hari. Sehingga self-efficacy remaja cenderung negatif karena kekuatan keyakinan diri tidak didukung dengan implementasi yang nyata.

Pada tabel 3 dapat dilihat bahwa perilaku seksual remaja cenderung berisiko. Penilaian perilaku yang terdiri dari ketiga komponen yaitu pengetahuan, sikap, dan tindakan di titik beratkan pada tindakan/aktifitas yang dilakukan sehari-hari. Sehingga hasil penelitian perilaku seksual remaja menunjukkan bahwa hampir seluruhnya termasuk dalam kategori berisiko.

Pada tabel 4 menunjukkan bahwa hasil uji statistik menggunakan Spearman diperoleh derajat signifikansi sebesar $\mathrm{p}=0,000$ dengan menetapkan derajat signifikansi $\alpha<0,05$ maka H1 diterima yang berarti ada hubungan signifikan yang cukup kuat dan tidak searah antara self-efficacy dalam menghindari seks bebas dan HIV/AIDS dengan perilaku seksual remaja. 
Tabel 1. Karakteristik responden

\begin{tabular}{|c|c|c|}
\hline Karakteristik & $\mathbf{f}$ & $\%$ \\
\hline \multicolumn{3}{|l|}{ Usia } \\
\hline 17 Tahun & 58 & 45.7 \\
\hline 18 Tahun & 49 & 38.6 \\
\hline 19 Tahun & 20 & 15.7 \\
\hline \multicolumn{3}{|l|}{ Jenis Kelamin } \\
\hline Laki-Laki & 61 & 48.0 \\
\hline Perempuan & 66 & 52.0 \\
\hline \multicolumn{3}{|l|}{ Status Saat Ini } \\
\hline Tidak Berpacaran & 66 & 52.0 \\
\hline Berpacaran & 61 & 48.0 \\
\hline \multicolumn{3}{|l|}{ Status Sebelumnya } \\
\hline Tidak Pernah Berpacaran & 21 & 16.5 \\
\hline Pernah Berpacaran & 106 & 83.5 \\
\hline \multicolumn{3}{|l|}{ Informasi Cara Menghindari Perilaku Beresiko } \\
\hline Tidak/Belum Pernah Menerima Informasi & 15 & 11.8 \\
\hline Pernah Menerima Informasi & 112 & 88.2 \\
\hline \multicolumn{3}{|c|}{ Informasi Cara Menghindari Seks Bebas dan HIV/AIDS } \\
\hline Tidak/Belum Pernah Menerima Informasi & 14 & 11.0 \\
\hline Pernah Menerima Informasi & 113 & 89.0 \\
\hline \multicolumn{3}{|c|}{ Faktor yang Membantu Menghindari Perilaku Beresiko } \\
\hline Dukungan Sosial & 76 & 59.8 \\
\hline Kebiasaan Perilaku & 32 & 25.2 \\
\hline Kepercayaan Diri/Self-Efficacy & 19 & 15.0 \\
\hline
\end{tabular}

Tabel 2. Self-efficacy remaja dalam menghindari seks bebas dan HIV/AIDS di SMKN 1 Kota Blitar per Desember 2018

\begin{tabular}{|c|c|c|}
\hline Variabel & $\mathbf{f}$ & $\%$ \\
\hline \multicolumn{3}{|l|}{ Self-Efficacy } \\
\hline Rendah & 65 & 51 \\
\hline Tinggi & 62 & 49 \\
\hline Total & 127 & 100 \\
\hline
\end{tabular}

Tabel 3. Perilaku seksual remaja di SMKN 1 Kota Blitar per Desember 2018

\begin{tabular}{|c|c|c|}
\hline Variabel & f & $\%$ \\
\hline Perilaku & & \\
\hline Tidak Berisiko & 44 & 35 \\
\hline Berisiko & 83 & 65 \\
\hline Total & 127 & 100 \\
\hline
\end{tabular}

Tabel 4. Hubungan self-efficacy dalam menghindari seks bebas dan HIV/AIDS dengan perilaku seksual remaja di SMKN 1 Kota Blitar per Desember 2018

\begin{tabular}{|c|c|c|c|c|c|c|}
\hline \multirow{3}{*}{ Self-Efficacy } & \multicolumn{6}{|c|}{ Perilaku } \\
\hline & \multicolumn{2}{|c|}{ Tidak Berisiko } & \multicolumn{2}{|c|}{ Berisiko } & \multicolumn{2}{|c|}{ Total } \\
\hline & $\mathbf{f}$ & $\%$ & f & $\%$ & f & $\%$ \\
\hline \multirow{4}{*}{$\begin{array}{l}\text { Rendah } \\
\text { Tinggi }\end{array}$} & 9 & 7 & 56 & 44 & 65 & 51 \\
\hline & 35 & 28 & 27 & 21 & 62 & 49 \\
\hline & 44 & 35 & 83 & 65 & 127 & 100 \\
\hline & & an Rho & $p$ value $=0.000$ & $r=-0.448$ & & \\
\hline
\end{tabular}

\section{PEMBAHASAN}

Dari hasil penelitian menunjukkan bahwa ada hubungan signifikan yang cukup kuat dan tidak searah antara self-efficacy dalam menghindari seks bebas dan HIV/AIDS dengan perilaku seksual remaja di SMK Kota Blitar. Hubungan antar kedua variabel bersifat tidak searah artinya apabila semakin rendah kemampuan self-efficacy maka semakin tinggi perilaku seksual berisiko, dan sebaliknya. Dari analisis data menunjukkan bahwa dua dari tiga komponen variabel self-efficacy, magnitude dan generalizability, hampir seluruh responden berada pada kategori negatif. Sementara komponen variabel self-efficacy yang paling menonjol dimiliki oleh responden adalah keyakinan kekuatan diri (strength of belief), sebanyak 68 responden (53\%) termasuk pada kategori positif. Pada variabel perilaku seksual, subvariabel tingkat pengetahuan dan sikap keduanya termasuk pada kategori negatif. 
Hasil analisis data penelitian ini serupa dengan penelitian milik Muflih dan Setiawan (2017) dan Mitchell et al. (2017) yang menyebutkan bahwa salah satu faktor yang menyebabkan perilaku seks bebas pada remaja adalah tingkat kemampuan selfefficacy remaja dalam menjauhi perilaku berisiko masih rendah. Hal ini juga mendukung penelitian milik Winarni (2017) yang menyebutkan bahwa ada pengaruh efikasi diri dengan perilaku seksual pranikah, dimana semakin tinggi efikasi siswa maka semakin mengurangi perilaku seksual pranikah. Menurut Winarni (2017) faktor yang menyebabkan perilaku seks pranikah pada remaja antara lain kurangnya pengetahuan tentang kesehatan reproduksi yang sudah mulai berkembang kematangan seksual secara lengkap, adanya penyebaran informasi dan rangsangan seksual melalui media massa.

Remaja yang bersifat cenderung ingin tahu dan ingin mencoba serta ingin meniru apa yang dilihat atau didengarnya belum memahami informasi yang diberikan oleh guru BK, tim Generasi Berencana (GENRE) dari BKKBN, maupun konselor HIV/AIDS Dinas Kesehatan Kota Blitar secara optimal sehingga direfleksikan pada perilaku seksual yang cenderung berisiko. Kondisi demikian juga bisa disebabkan informasi yang diterima siswa/i pada umumnya hanya bersifat superfisial yang masih kurang menggambarkan kesehatan reproduksi secara menyeluruh. Hal ini dibuktikan dengan hasil analisis data yang menunjukkan 110 responden (87\%) termasuk dalam kategori tingkat pengetahuan rendah. Sementara berdasarkan wawancara kepada tim GENRE dan Guru BK SMK Blitar menyatakan bahwa setiap tahun ajaran baru, seluruh siswa/i mendapatkan seminar mengenai kesehatan reproduksi remaja, napza, serta menghindari perilaku seksual berisiko. Kegiatan tersebut juga diklarifikasi oleh pernyataan responden bahwa hampir seluruhnya pernah mendapatkan informasi mengenai pencegahan seks bebas dan perilaku seksual berisiko.

Berdasarkan teori Bandura (1998) efikasi diri memengaruhi mekanisme perilaku manusia, apabila seseorang yakin mempunyai kemampuan untuk menghasilkan sesuatu yang diinginkan maka individu akan berusaha untuk mencapainya. Efikasi diri penting dimiliki oleh remaja agar mampu terus menghadapi segala perubahan yang terjadi. Hal ini didukung dengan Teori Pembelajaran Sosial (Social Learning Theory) Bandura yang menyebutkan bahwa pembelajaran didasarkan pada keyakinan tentang perilaku manusia ditentukan oleh hubungan tiga arah antara faktor kognitif, pengaruh lingkungan, dan perilaku.

Siswa/i usia remaja tetap membutuhkan pendidikan mengenai seks bebas, HIV/AIDS, dan perilaku seksual meskipun remaja mengaku sudah pernah terpapar informasi sebelumnya. Sehingga alangkah lebih baik bila tim konselor (BK, peer counselor) yang ada di sekolah, serta perawat pendidik tetap memberikan pembelajaran secara spesifik dari ketiga aspek tersebut. Berdasar teknik penerapan social learning theory oleh Bandura, pendidikan yang dapat diberikan pembelajar yaitu untuk: 1) Mengamati dan meniru perilaku orang lain,

2) Melihat perilaku positif untuk dimodelkan dan dipraktikkan, 3) Meningkatkan kemampuan dan kepercayaan diri mereka sendiri untuk menerapkan ketrampilan baru, 4) Mendapatkan sikap positif/respon positif tentang penerapan keterampilan baru, dan 5) Memberikan pengalaman dukungan dari lingkungan mereka untuk menggunakan keterampilan baru.

\section{KESIMPULAN}

Komponen kemampuan Self-efficacy remaja yaitu magnitude, dan generalizability, keduanya termasuk dalam kategori negatif. Perilaku siswa/i membuktikan bahwa; a) Tingkat pengetahuan responden dalam kategori rendah, b) Sikap yang direfleksikan dalam kehidupan sehari-hari termasuk kategori sikap negatif, dan c) Tindakan/aktifitas seksual responden seluruhnya termasuk dalam kategori pernah melakukan kegiatan seksual pranikah. Sehingga perilaku responden cenderung berisiko.

Berdasarkan hasil penelitian yang diperoleh, maka dapat diberikan saran sebagai berikut: 1) Melakukan evaluasi tingkat pengetahuan, sikap, dan tindakan/aktifitas siswa/i setelah mendapatkan konseling, seminar, atau kegiatan informatif lainnya, 2) Meningkatkan kualitas konten dalam pendidikan seksual terutama dalam hal peningkatan keyakinan diri untuk menghindari perilaku berisiko (self-efficacy), 3) Melibatkan siswa/i dalam tindakan pencegahan timbulnya perilaku berisiko, seperti menjadikan duta remaja, tim penyuluh dalam menghindari perilaku berisiko, serta sharing session bersama orang dengan HIV/AIDS (ODHA) yang sedang berjuang maupun telah berhasil melewatinya.

\section{DAFTAR PUSTAKA}

Afritayeni, Yanti, P. D. and Angrainy, R. (2018)

'Analisis perilaku seksual berisiko pada remaja terinfeksi hiv dan aids', Jurnal Endurance, 3(1), pp. 69-81.

Bandura (1998) 'Self-Efficacy Albert Bandura Stanford University Bandura, A. (1994). Selfefficacy. In V. S. Ramachaudran (Ed.), Encyclopedia of human behavior (Vol. 4, pp. 7181). New York: Academic Press. (Reprinted in H. Friedman [Ed.], Encyclopedia of mental health. ', 4(1994), pp. 71-81. doi: 10.1002/9780470479216.corpsy0836.

Istiqomah, N. and Notobroto, H. B. (2017) 'Pengaruh Pengetahuan, Kontrol Diri terhadap Perilaku Seksual Pranikah di Kalangan Remaja SMK di Surabaya', Jurnal Biometrika dan Kependudukan, 5(2), pp. 125-134. doi: 10.1016/S0140- 


\section{6(52)91196-3.}

Mitchell, C. M. et al. (2017) 'Self-Efficacy About Sexual Risk / Protective Behaviors : Intervention Impact Trajectories Among American Indian Youth', pp. 1-8. doi: 10.1111/jora.12308.

Morrison- Beedy, D. et al. (2017) 'Understanding the "Why" for High-Risk Behavior: Adolescent Girls' Motivations for Sex', Journal of the Association of Nurses in AIDS Care. Elsevier Inc, 28(6), pp. 877887. doi: 10.1016/j.jana.2017.06.012.

Muflih, M. and Setiawan, I. D. (2017) 'Pengaruh Konseling Short Message Service (SMS) Gateway terhadap Self Efficacy Menghindari Seks Bebas dan HIV/AIDS Remaja', Jurnal Keperawatan Padjajaran, 5(April 2017), pp. 1-9.

Muflih, M. and Syafitri, E. N. (2018) 'DENGAN KUESIONER', 5(September), pp. 438-443.

Puspita, L. (2017) 'Infeksi Menular Seksual Pada Wanita Pekerja Seksual', 2(1), pp. 31-44.

Winarni (2017) 'Efikasi diri dan perilaku seksual pranikah remaja sma', $\mathrm{XV}(2)$. 